\title{
Lip and Oral Cavity Cancer pT4b TNM Finding v8
}

National Cancer Institute

\section{Source}

National Cancer Institute. Lip and Oral Cavity Cancer pT 4b TNM Finding v8. NCI

Thesaurus. Code C132700.

Lip and oral cavity cancer with very advanced local disease. Tumor invades masticator space, pterygoid plates, or skull base and/or encases the internal carotid artery. (from AJCC 8th Ed.) 